\title{
PLEISTOCENE GLACIATION IN THE COMMONWEALTH OF AUSTRALIA
}

\author{
By W. R. BRowne \\ (Late Reader in the Department of Geology, University of Sydney)
}

\begin{abstract}
Pleistocene glaciation in the Commonwealth of Australia is confined to Tasmania and a small area on the mainland, chiefly in the Kosciusko plateau of New South Wales. Three glacial stages of decreasing intensity have been recognized-the Malannan, Yolande and Margaret Stages. These are characterized by ice cap, valley glacier and cirque conditions respectively. At its maximum the ice cover extended down to sea-level in western and southern Tasmania, but in New South Wales traces are not known below $1448 \mathrm{~m}$. From consideration of snow line etc. it is estimated that during the maximum glaciation the temperature was about $13^{\circ} \mathrm{F} .\left(7 \cdot 2^{\circ} \mathrm{C}\right.$.) lower than it is to-day,
\end{abstract}

Zusammenfassung. Die zum Pleistozän gehörige Vergletscherung im Staat Australien beschränkt sich auf Tasmanien und ein kleines Gebiet auf dem Festland, hauptsächlich dem Kosciusko Plateau in Neusüdwales. Drei Gletscherstadien abnehmender Grösse sind festgestellt worden, nämlich die Malannan, Yolande und Margaret Stadien. Diese sind jeweils durch Eiskappen, Talgletscher und Kare charakterisiert. Im Hochstand erstreckte sich die Vergletscherung in West- und Süd-Tasmanien bis an den Meeresspiegel, aber in Neusüdwales sind Spuren unter $1448 \mathrm{~m}$. nicht bekannt. Unter Erwägung der Schneegrenze usw. wurde berechnet, dass während der maximalen Vergletscherung die Temperatur ungefähr $7,2^{\circ} \mathrm{C}$. niedriger war als heute.

OwING to its geographical situation and a general absence of lofty mountains Australia has no glaciers to-day. In Tasmania and New South Wales, however, there is evidence of Pleistocene glaciation between lat. $36^{\circ} 7 \frac{1}{2}^{\prime}$ and $43^{\circ} 36^{\prime} \mathrm{S}$. Much of this terrain is relatively inaccessible and has not yet received detailed treatment.

\section{TASMANIA}

The principal highlands are those forming the Central Highlands or Central Plateau, averaging $1000 \mathrm{~m}$. in altitude but attaining $1400 \mathrm{~m}$. in the north, with monadnocks rising to $1500 \mathrm{~m}$. above sea level.* On its eastern and north-eastern flank the Central Plateau drops abruptly $600 \mathrm{~m}$. to the Midlands sunkland, the latter being bounded further east by highlands rising locally to more than $1500 \mathrm{~m}$. The major topographic features of Tasmania are largely the result of repeated Cainozoic faulting.

In Tasmania the late Dr. A. N. Lewis tentatively recognized at least three glacial stages of decreasing intensity; these are the Malannan, Yolande and Margaret Stages, the first being characterized by ice caps, the second by alpine or valley glaciers, and the third by cirque glaciers. Glacierization was more severe in the west, where precipitation from the prevailing onshore westerlies was greatest.

\section{Malannan Stage}

The glacierization affected about $31,000 \mathrm{~km} .^{2}$ although probably only $10,000 \mathrm{~km} .{ }^{2}$ were icecovered. The ice caps, $600 \mathrm{~m}$. thick in the west, spread over the highlands, and descended to sealevel in the south-west and south.

Most of the large, shallow lakes of the Central Plateau occupy hollows probably scooped out by ice, and elsewhere the surface was swept bare of boulders and soil. In the north-west roches moutonnées occur from the head of the Forth River south to the plateau east of Lake St. Clair. Several peaks and ridges of the West Coast Range are glaciated to their summits while the drowned inlet of Port Davey in the south-west was thought by Lewis to be a glaciated fjord, but this view is now generally discredited. In National Park and elsewhere in the Southern Plateau the effects of the Malannan have been largely obscured by those of the Yolande Stage.

Outlet glaciers pushed from the plateaux far down the valleys to low levels, gouging them out widely and deeply. Examples of such valleys are those of the Upper Mersey and Forth in the north. In the west and south the Pieman River and most of the river valleys as far south as the La Perouse Range show some evidence of this glaciation.

\footnotetext{
* For illustrations see pages 113 and 123
} 
Moraine-dammed lakes bounded by nunatak ridges are numerous on the moorland plateau west of the Great Lake, and a large area at the head of the Mersey and Pine Rivers is studded with hundreds of tarns and lagoons lying in irregular hollows of hummocky drumlin-like moraine deposited by ice moving from the north-west. The Barn Bluff monadnock is mantled with coarse moraine, and south and west of it rounded ridges and low hummocks of moraine enclose innumerable lakelets. Much glacial debris, including boulders of 500 tons, has been deposited in the West Coast Range and on the Western Plateau, sometimes at low levels. Near Queenstown varved clays are associated with moraine, and on the north-eastern shore of Macquarie Harbour and elsewhere, where piedmont glaciers formed near sea-level, there are terraces of outwash gravel and shingle with layers of peat that pass below sea-level. In the extreme south the lowland plain behind Recherche Bay is thickly strewn with glacial debris from another piedmont glacier, and a few miles inland the wide D'Entrecasteaux valley is crossed by a great moraine ridge $300 \mathrm{~m}$. high.

It was probably during the Malannan Stage that the plateau remnant of Mt. Wellington (1270 m.) near Hobart and the higher parts of the north-eastern plateau about Ben Lomond, Mt. Barrow and Mt. Victoria were glacier-covered.

\section{Yolande Stage}

To the Yolande glaciers is due most of the striking and picturesque glacial scenery of Tasmania. They descended to $670 \mathrm{~m}$. on the east and somewhat lower on the west, occupying the upper parts of valleys shaped by Malannan glaciers. Their chief physiographic expression is in straight, $\mathrm{U}$-shaped, cirque-headed and spurless swampy upland valleys, beautiful medial and lateral moraines, moraine-dammed lakes, rock-basins, and stepped and hanging valleys. Cirques may be separated by razorback cols or by jagged, saw-toothed ridges, while many ranges, such as the Eldon and the Denison, are characterized by scalloped ridges formed by cirque erosion. The lakes are commonly paired, one being $100-120 \mathrm{~m}$. above the other, a possible indication of two separate phases of the stage. Yolande moraines are generally fresher than Malannan, and the cirques and glaciated valleys are on a much larger scale than those of the Margaret Stage and extend to much lower levels, but differentiation of the stages may be difficult.

On the Central Plateau the glaciers left deep impressions, particularly in the west and northwest. From a centre about Cradle Mt. and Barn Bluff the ice streamed along radial valleys which originate in steep-walled cirques. One of these, $275 \mathrm{~m}$. in total depth, contains Dove Lake, $60 \mathrm{~m}$. deep. Rock surfaces are smoothed and polished, and at the northern end of Cradle Mt. opposing cirques are separated by a jagged ridge. The glaciated valleys contain much lateral, recessional and ground moraine.

Lake St. Clair (730 m.) occupies a deep glacier-cut valley depression $\mathrm{r} 6 \mathrm{~km}$. long, blocked by a moraine $10 \mathrm{~km}$. long and $230 \mathrm{~m}$. high. Up-stream the valley continues, with a broad swampy floor, to head in a great multiple cirque. South of Lake St. Clair other glaciers from east and west converged on the main glacier, which continued for several miles along the valley of the Derwent. Further west the Upper Franklin River flows in a perfect glacial valley containing two small lakes, one of which occupies a rock-basin, as well as several recessional moraines and roches moutonnées.

Probably many of the glacial features in the headwater valleys along the western margin of the Central Plateau and its projections are of Yolande age. This is also the case in the Eldon and King William Ranges, as well as in various parts of the West Coast Range, including Mts. Murchison, Tyndall, Jukes and Darwin. These are cut into by large cirque-headed valleys. On the east side of Mt. Jukes is a Yolande-age composite cirque with two lakes at $8 \mathrm{I} O$ and $7 \mathrm{I}_{5} \mathrm{~m}$. respectively. Mt. Murchison $(1340 \mathrm{~m}$.) is a former nunatak from which radiate cirque-headed glacial valleys notable for their beautiful medial moraines.

Relics of the Yolande ice cover are well displayed in National Park, where the biggest glacier moved north down the valley of Broad River for $\mathrm{II} \mathrm{km}$. and terminated at an altitude of $730 \mathrm{~m}$. This straight valley, heading in a great cirque, has walls rising $150 \mathrm{~m}$. above a wide, swampy floor crossed by at least five recessional moraines, behind which are the boulder-studded clays of former 
All the cirques form the heads of valleys tributary to the Huon, Weld and other wide valleys once occupied by Malannan ice. Their floors are strewn with moraine and outwash material from the Yolande glaciers, which were less than $5 \mathrm{~km}$. long.

The plateau of the La Perouse Range, I roo to $1200 \mathrm{~m}$., originally sculptured by a Malannan ice cap and its overflow glaciers, was carved by Yolande glaciers into a sinuous ridge with narrow lateral spurs, in which deep valley-head cirques, razorback cols and jagged ridges are conspicuous. The glaciers must have been at least $300 \mathrm{~m}$. thick and up to $\mathrm{r} \cdot 6 \mathrm{~km}$. wide, but it is uncertain how far they travelled down the old glacial valleys. A few rock-basin and moraine-dammed lakes appear on the cirque floors, and there is evidence of cirque erosion at two levels differing by $150 \mathrm{~m}$.

\section{Margaret Stage}

Cirques, roches moutonnées and other features due to this glaciation are found at $1200 \mathrm{~m}$. on the Central Plateau but as low as $730 \mathrm{~m}$. in the West Coast Range. Tarns and cirques with walls about $180 \mathrm{~m}$. high are perched $300 \mathrm{~m}$. above those of the Yolande Stage, and some groups of cirques have become merged to form a glacial ledge or shelf. Evidence of this glaciation is plentiful in the higher parts of the Central Plateau. In the neighbourhood of Lake St. Clair is the glacial horn of Mt. Ida and its associated cirques as well as a number of cirques on the Mt. Olympus ridge and in the Du Cane Range. Little cirque lakes are found high on Mt. Murchison while Eldon Peak ( $1450 \mathrm{~m}$.) appears to be a glacial horn surrounded by cirques. In the West Coast Range at the heads of the Henty and King Rivers are rock-basins and glacial lakes such as Lakes Rolleston, Dora and Margaret, the last-named lake being drained by a stream that tumbles $300 \mathrm{~m}$. into the valley of Yolande River.

Cirques and cirque lakes are numerous in the Denison Range, and in National Park there is a particularly fine glacial shelf with nine tarns held in rock-basins or behind moraines. The overflow plunges over falls $360 \mathrm{~m}$. high into lakes now occupying valleys that were glacier-covered in Yolande times.

Around Mt. Anne are several small cirques at $1200 \mathrm{~m}$., and ledges and tarns appear at $900 \mathrm{~m}$. in the walls of the cirque-headed valleys of La Perouse Range. One monadnock peak has been fashioned into a great pyramidal horn.

\section{New South Wales}

The glaciated country comprises some $1000 \mathrm{~km} .^{2}$ in the Kosciusko plateau, the highest part of the Southern Highlands, near the Victorian border. The plateau, $5^{\circ} \mathrm{km}$. long, is a meridional horst apparently step-faulted to east and west and dropping rather abruptly at both northern and southern ends, possibly through cross-faulting. There also appears to be a great fault throwing south-east along the Thredbo (Crackenback) River, and there may be others parallel with it. The plateau was raised to its present level at about the end of Tertiary time.

Much of the country is over $1800 \mathrm{~m}$., while a small area around Mt. Kosciusko (2230 m.) exceeds $2100 \mathrm{~m}$. The Upper Murray and the Snowy River systems have cut deep into the horst. The plateau contains the Main Divide of eastern Australia, which traverses most of the highest land, although in places the surface rises higher to the west of it, notably in Mt. Townsend (2210 m.), and $20 \mathrm{~km}$. to the north-north-east in the ridge known as The Kerries (c. $2000 \mathrm{~m}$.). The terrain is predominantly granitic. Throughout the region virtually all the higher topographic features are of glacial origin.

As in Tasmania the glaciation appears to have had three stages, marked by ice caps, valley glaciers and cirque glaciers respectively. Traces of the first and second have been found down to $1450 \mathrm{~m}$., and of the third to about $\mathrm{I} 800 \mathrm{~m}$. At the lower levels rivers were eroding during the glaciations as well as in inter-glacial and post-glacial times. Glacierization was more extensive on the eastern than on the western side of the Main Divide, largely because of the steeper western slope. From a consideration of the snow line it is calculated that during the maximum glacierization the temperature was about $13^{\circ} \mathrm{F} .\left(7 \cdot 2^{\circ} \mathrm{C}\right.$.) lower than it is now.

To the first glacierization are assigned the broadly rounded profiles characteristic of the region. 
Many asymmetrical convex ridges have the appearance of great roches moutonnées with gentle westward slopes and plucked faces to the east. Some of the higher projections on the plateau were evidently nunataks. Ground-moraine of granite boulders, great and small, is scattered thickly over the surface, particularly at the higher levels, and occasional blocks of acid granite, quartzite and phyllite indicate a carry of up to I I km. from the gathering-ground near the Main Divide. The ice, probably more than $300 \mathrm{~m}$. thick, crossed in its eastward course the valleys, much shallower then than now, of the Upper Snowy River and its tributaries, mounted the low Ramshead Range forming the watershed between the Snowy and Crackenback Rivers, and sent lobes down the sides of the Crackenback valley. This range is diversified by occasional wide, shallow, erratic-filled cols through which the dwindling ice lobes pushed their way. Farther north the ice came from the Kerries ridge, and a number of large roches moutonnées may be seen between it and the Divide, and on the Divide itself.

Of the second glacierization, which may have had three phases, spurless U-shaped valleys are the most conspicuous evidence. During that period the upland valleys east and west of the Main Divide were partially filled with ice. The Upper Snowy valley contained a glacier fed by many tributaries from both sides, whose course is traceable for about $21 \mathrm{~km}$. down to a level of $1525 \mathrm{~m}$. Throughout its length the plateau is characterized by glacial valleys, some heading in cirques that are mostly shallow but may exceptionally be $270 \mathrm{~m}$. deep. Many tributaries of the Upper Snowy River flow in collinear glaciated valleys separated by rounded, erratic-strewn cols; similar cols commonly appear on the Main Divide. There are numbers of hanging valleys with a drop of as much as $60 \mathrm{~m}$., and many valleys are stepped, the edge of the tread being covered with moraine, the breached barrier of a drained lake. The valleys contain ground-moraine and lateral moraine and are crossed by recessional moraines, the largest of which-the David moraine-is $I \cdot 2 \mathrm{~km}$. long and more than $45 \mathrm{~m}$. high. Drained lakes are indicated by creeks meandering over swampy lake deposits behind breached moraines. One such deposit includes $30 \mathrm{~cm}$. of varved clays, the only known Pleistocene example on the mainland of Australia.

Truncated spurs are well seen in the valley of the Snowy River $16 \mathrm{~km}$. from its source, where there has been overdeepening to the extent of nearly $150 \mathrm{~m}$., and also in the valleys of Guthega River, Spencer's Creek and other tributaries.

The valley of the Crackenback River above $1500 \mathrm{~m}$. is glaciated, and certain of its tributaries on the plateau on its right bank flow in glaciated, swampy, upland valleys.

Most of the valleys west of the Main Divide are glaciated in their headward parts, but pass down within a few kilometres into youthful gorges resulting from post-glacial rejuvenation.

The evidences of the third glacierization comprise cirques and rock-basins at high levels, with lateral and terminal moraines. To this stage are assigned a small number of moraine-dammed cirque lakes within a few kilometres' radius of Mt. Kosciusko, at or near the heads of valleys that formerly held glaciers of the second stage; the largest is Lake Albina, $580 \mathrm{~m}$. long. Most of the lakes are shallow, but the Blue Lake, in a rock-basin, is $27.4 \mathrm{~m}$. deep and partly blocked by moraine. Below this lake a festoon of four or five crescentic terminal and lateral moraines extends down towards the Snowy River, and perched upon them is the shallow Hedley Tarn. The tiny Club Lake, backed by a steep wall $150 \mathrm{~m}$. high, is perched $120 \mathrm{~m}$. above the floor of a cirque belonging to the second glacierization.

From the high country in north-eastern Victoria evidence of glaciation has recently been reported, and it is possible that relict glacial features may yet be found in New South Wales north of the Kosciusko plateau and in the higher uplands in the west of the Australian Capital Territory, some of which exceed $1800 \mathrm{~m}$.

\section{MS. received 6 April 1956}

\section{B I B L I O G R A P H Y}

Lewis, A. N. Pleistocene glaciation in Tasmania. Papers and Proceedings of the Royal Society of Tasmania for the year 1 944 , [pub.] 1 945 , p. $41-56$. [With full bibliography.]

Browne, W. R. Pleistocene glaciation in the Kosciusko region. (In Glaessner, M. F., and Rudd, E. A., ed. Sir Douglas Mawson anniversary volume. Adelaide, University of Adelaide, 1952, p. 25-41. [With references.])

Browne, W. R. Our Kosciusko heritage. Australian fournal of Science, Supplement, Vol. 15, No. 3, 1952, p. i-viii. 
